\title{
Record of New Bryophytes for Iraqi Bryoflora
}
B. A. Basheer Al-N'ima ${ }^{(1)}$
Abdul-Hussein Al-Khyat ${ }^{(2)}$
(1) Dept. of Biology, College of Sciences, University of Mosul,
(2) The Iraqi National Herbarium, Abu Graib, Baghdad.

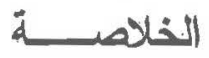

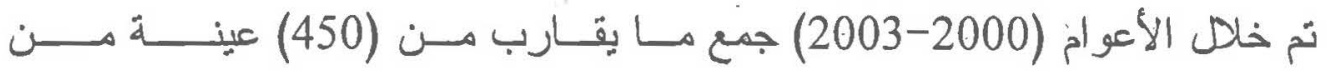

الحزازيات المورقة (mosses) و الكبدية (liverworts) من شـــال العـراق.و بالدرجــة

الرئيسة من محافظات دهوك وأربيل ونينوى. وقد أظهر تشخيص العينات أنها نعود إلى (40)

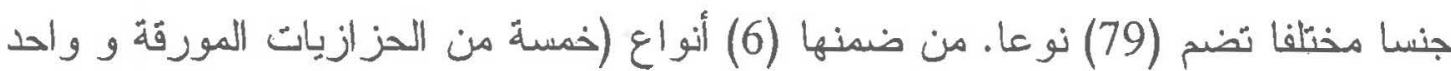

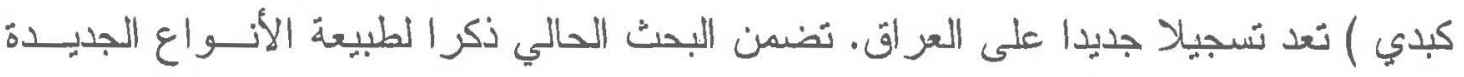
فضلا عن مو اطنها البيئية و توزيعها في العالم وكذلك في المناطق الجغر افية الطبيعية للعر اق. الأجناس المسجلة حديثا هي:

1- Fossombronia Raddi (Liverwort)

2- Ditrichum Hampe

3- Phascum Hedw.

4- Racomitrium Brid.

1- Brachythecium rutabulum (Hedw.) Br. Eur.

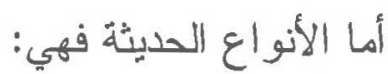

2- Ditrichum homomallum (Hedw.) E.G. Britton

3- Fossombronia caespitiformis De Not.

4- Phascum curvicolle Hedw.

5- Phascum cuspidatum Hedw. var. Piliferum (Hedw.) Hook et Tayl.

6- Racomitrium affine (Schleich. ex Web. et Mohr) Lindb

\section{ABSTRACT}

During the years (2000-20003) about (450) Specimens of mosses and liverworts have been collected from the north part of Iraq, mainly Dohuk, Erbil and Nineveh provinces. Identification revealed that they were belong to (40) genera and (79) species. Among them (4) genera and six species ( 5 mosses and one liverwort) were considered new record for Iraq. Habitat of the new taxa beside their distribution in the world and Iraqi physiographic regions \& districts were included in the present work.

The new-recorded genera are:

1- Fossombronia Raddi (Liverwort)

3-Phascum Hedw.

2- Ditrichum Hampe

4- Racomitrium.Brid.

'Presented at the first conference on Biology, University of Mosul ,college of Education, 4-5 September 2007 
While the New species are:

1-Brachythecium rutabulum (Hedw.) Br. Eur.

2-Ditrichum homomallum (Hedw.) E. G. Britton

3-Fossombronia caespitiformis De Not.

4-Phascum curvicolle Hedw.

5-Phascum cuspidatum Hedw. var. Piliferum (Hedw.) Hook et al.

6-Racomitrium affine (Schleich. ex Web. et Mohr) Lindb.

\section{INTRODUCTION:}

In Iraq and adjacent Arabian countries, there was little interest in the bryophytes that reflected by the number of related studies especially by local scientists. The first paper included a sign for Iraqi Bryoflora has been published in (1870) by ${ }^{(1)}$. Since that time up to date (i.e. over 125 years) only (13) works have been occurred they are ${ }^{(1-13)}$. Those papers that published before (1991) had been reviewed by ${ }^{(14)}$.After them only two papers have been published ${ }^{(12 \& 13)}$. Most of these works are actually a list of species and their distribution places, included no description and identification keys. Consequently, the bryoflora image of this country is still out of focus and many works have to be conducted to improve it. This fact draws our attention to consider this group of plants. The first stage of consideration must include, as we think, a series of surveying studies, like the present one, to cover all physiographic regions \& districts of Iraq.

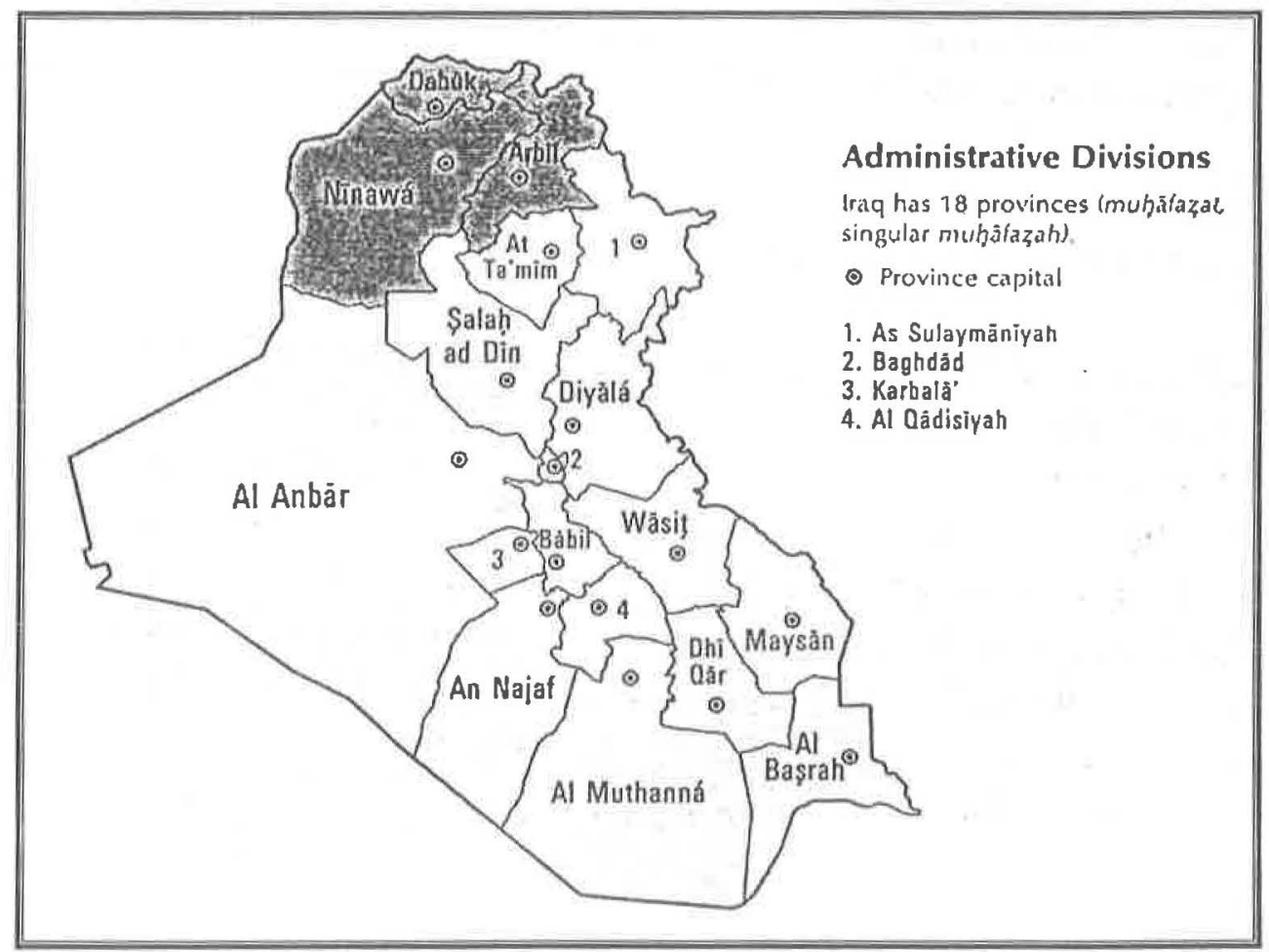

'Figure. 1' Iraqi Map showing studied area. 


\section{MATERIALS AND METHODS:}

During the years (2000- 2003) about (450) Specimens of mosses and liverworts were collected from the North part of Iraq mainly Dohuk, Erbil and Nineveh provinces (figure 1).The specimens were air dried, labeled, numbered and deposited at the herbarium of the College of Sciences, Department of Biology, University of Mosul (MUH). Then the taxa were examined and identified using the keys included in the following references $(10,15,16,17 \& 18)$.

To confirm the identification, the collected specimens have been compared with those found in Baghdad University Herbarium, and have been collected and identified by Agnew and Vondracek.

\section{RESULTS \& DISSCUSSION:}

Identification of the (450) mosses and liverworts specimens revealed that they are (79) different taxa belongs to (40) genera which intern belongs to (20) Families and (14) orders. Among them (4) genera and (6) species found to be new records for Iraqi bryoflora, since they have not been collected or mentioned before by any author of the (13) published works. Within the records, there is only one genus and one species of liverworts.

The new-recorded genera are:

1-Fossombronia Raddi, 1818 (Liverwort) 2-Ditrichum Hampe, 1867

3- Phascum Hedwig., 1801 4- Racomitrium Bridle, 1818

While the New species are:

1- Brachythecium rutabulum (Hedwig.) B. S. G., 1853.

2- Ditrichum homomallum (Hedwig.) Hampe, 1867.

3- Fossombronia caespitiformis (Raddi) Dumortier,

4- Phascum curvicolle Hedwig. 1801.

5- Phascum cuspidatum Hedwig. 1801 var. Piliferum (Hedwig.) W. J. Hooker et Taylor, 1818.

6- Racomitrium affine (Schleicher ex Weber et Mohr) Lindberg.1875

The present study will be concentrated, mainly, on the new taxa. Therefore, their habitat and distribution in the world beside physiographic regions \& districts of Iraq will be given below.

\section{1-Brachythecium rutabulum (Plate, $1 \mathrm{a} \& \mathrm{~b}$ )}

Habitat: Lax tufts or scattered shoot on soil under tree trunks and may be submerged in water.

-In the World; Europe, Iceland, Farose, Algeria, Micronesia, America, Tasmania, New Zeland, Hawaii, Syria, Lebanon, Palestine, Iran, Turkey, Aphganistan. 
-In Iraq; 1-Mountain Region-Amadiya District: Dohuk Gali by dam body, Al-Ni'ma 26 March 2003 no. 208 MUH.

2-Upper Plain and Foothill Region-Nineveh District: Water Purification plant on left bank of Tigris River at Mosul city, Al-Ni'ma 15 May 2002 no. 365 MUH.

2- Ditrichum homomallum (Plate,1 c\&d)

Habitat: Slightly silky, Yellowish green tufts on sandy soil. -In the world; Turkey, Iceland, North America and Europe.

-In Iraq; Mountain Region-Amadiya District: Zawita, Al-Ni'ma 17 March 2002 no. $260 \mathrm{MUH}$

\section{3- Fossombronia caespitiformis (Plate, $1 \mathrm{e} \& \mathrm{f}$ )}

Habitat: On shaded sandy soils and on soil under the rocks

-In the world; Lebanon, Jordan, Palestine, Oman, Cyprus, Turkey, Iran and Britain.

-In Iraq; Mountain Region-Amadiya District: Gali Zanta, Al-Ni'ma 4 June 2002 no. $394 \& 395$ MUH.

\section{4- Phascum curvicolle (Plate, 2 a)}

Habitat: On calcareous soil.

-In the world; Palestine, Turkey, Greece, Spain, Central and North Europe.

-In Iraq ; Mountain Region-Amadiya District: Dohuk Gali, by dam body, Al-Ni'ma 26 March 2002 no. 436 MUH.

\section{5- Phascum cuspidatum var. Piliferum (Plate, 2 b\&c)}

Habitat: Small plant look as an immature moss grows on soil in an open area.

-In the world; Syria, Jordan, Palestine, Iran, Turkey, Algeria, Morocco and North America.

-In Iraq; Upper Plain and Foothills Region-Upper Jazira District, Jadala, Al-ni'ma 14 March 2002 no. 105 MUH.

\section{6-Racomitrium affine (Plate, $2 \mathrm{~d}-\mathrm{f}$ )}

Habitat: erect moss forming small cushions in the mountain regions mainly on rocks, May be found also on tree trunks in the very humid areas.

-In the world; Turkey, Greece; North, West and Central Asia, Japan, Iceland, Greenland, North America and Europe.

-In Iraq; Mountain Region-Amadiya District: Denarta, Al-Ni'ma 4 June 2002 no. 180 MUH; Gali Zanta, Al-Ni'ma 4 June 2002 no. 194 MUH; Dohuk Gali by dam body, Al-Ni'ma 26 March 2002 no. 204 MUH; 
Zawita, Al-Ni'ma 17 March 2002 no. 262 MUH; Al-Shaikh Adi, AlNi'ma 16 April 2002 no. $284 \& 285$ MUH.

Mountain Region-Rwanduz District: Betwana, Al-Ni'ma 16 April 1992 no. 15 MUH, Baikhal village, Al-Khayat 10 March 2001 no. 39 MUH.

Richness degree of any bryoflora with plant species depends mainly upon availability and diversity of the suitable habitat. Scarcity of rain, low relative humidity and high temperature are considered as the most important factors affecting growth and distribution of Bryophytes. The climate of Iraq is of semi-arid type characterized by high mean annual air temperature, low atmospheric humidity and scanty rainfall ${ }^{(19)}$. Iraqi bryophytes flora considered poor ${ }^{(10)}$. Number of the Mosses and liverworts species recorded in Iraq and adjacent regions up to (1991) summarized in 'Table 1'. In comparing, one can easily find that Iraq occupies middle situation. In one

'Table 1' Numbers of the liverworts and moss species in Iraq and adjacent countries. The numbers computed from ${ }^{(2)}$.

\begin{tabular}{||l|c|c|c|}
\hline The Country & Liverworts & Mosses & Total \\
\hline Iran & 065 & 297 & 362 \\
\hline Iraq & 008 & 167 & 175 \\
\hline Jordan & 012 & 105 & 117 \\
\hline Kuwait & 000 & 019 & 019 \\
\hline Saudia Arabia & 023 & 098 & 121 \\
\hline Syria & 012 & 109 & 121 \\
\hline Turkey & 155 & 670 & 825 \\
\hline
\end{tabular}

Hand, it is poorer than Turkey \& Iran and, in the other, is richer than Syria \& Jordan. The sum of recorded taxa in the country, tends to increase with passing time, since very vast area of different habitat have never been visited by researchers yet, but the increasing number will not approach the Turkey one. 


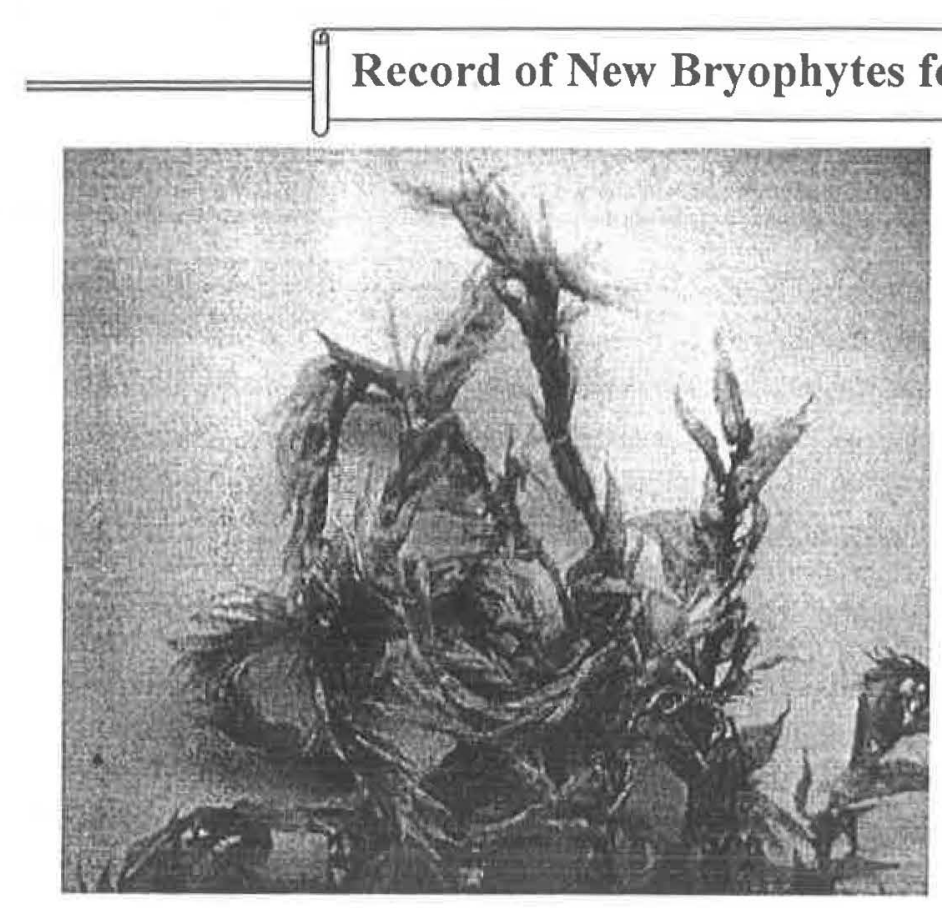

(A)

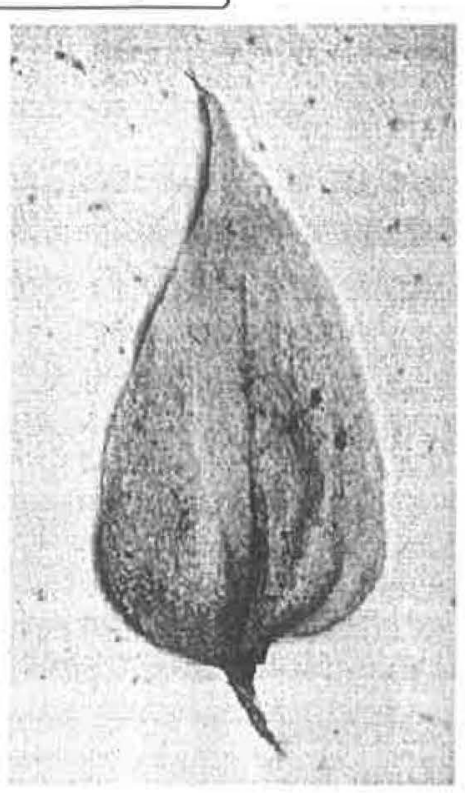

(B)

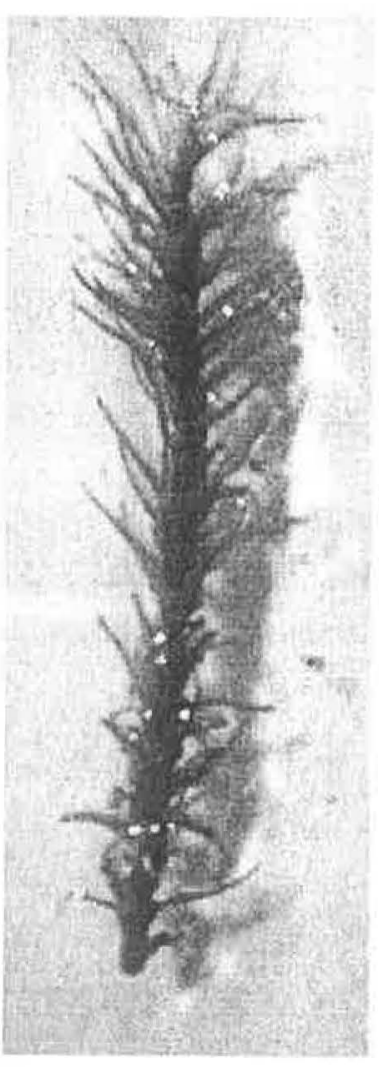

(C)

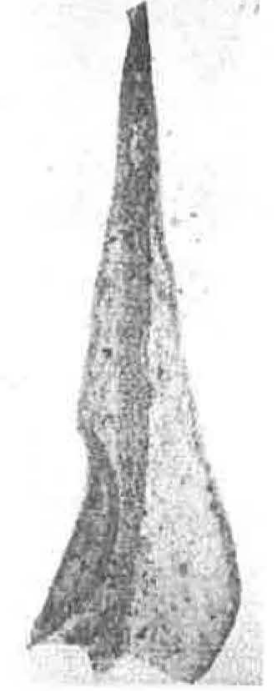

(D)

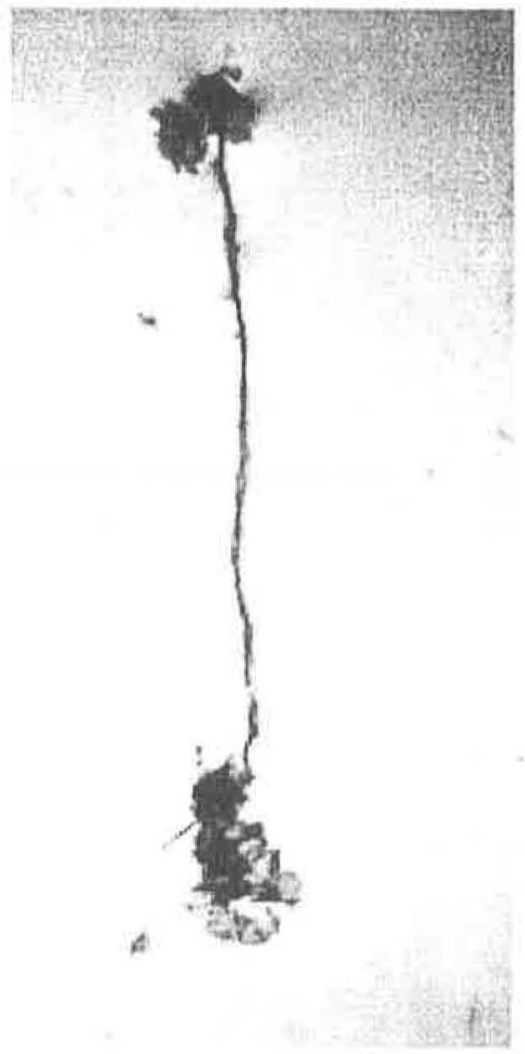

(E)

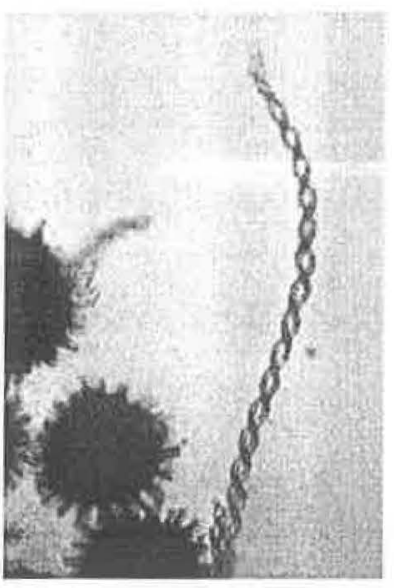

(F)

(Plate,1): A\&B, Brachythecium rutabulum gametophyte plant (x6) \& Leaf (x25); C \& D ,Ditrichum homomallum gametophyte plant (x7.5) \& leaf (x35); E\&F, Fossombronia caespitiformis whole plant (x13) \& spores with elater (x200). 


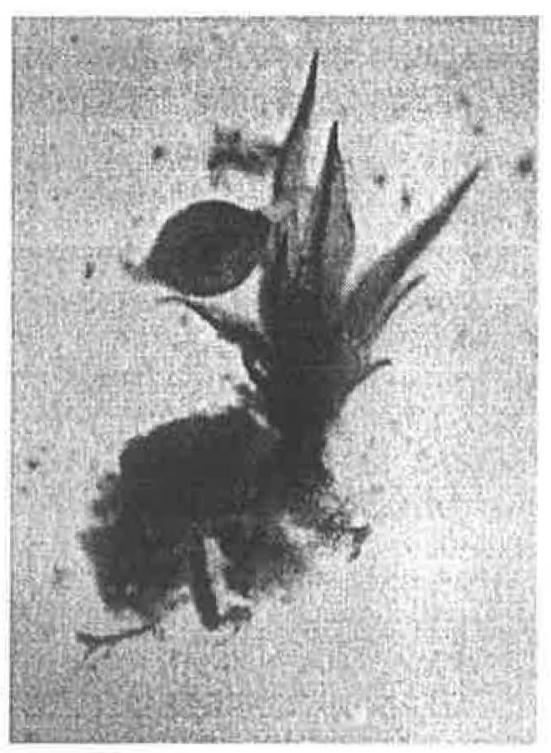

(A)

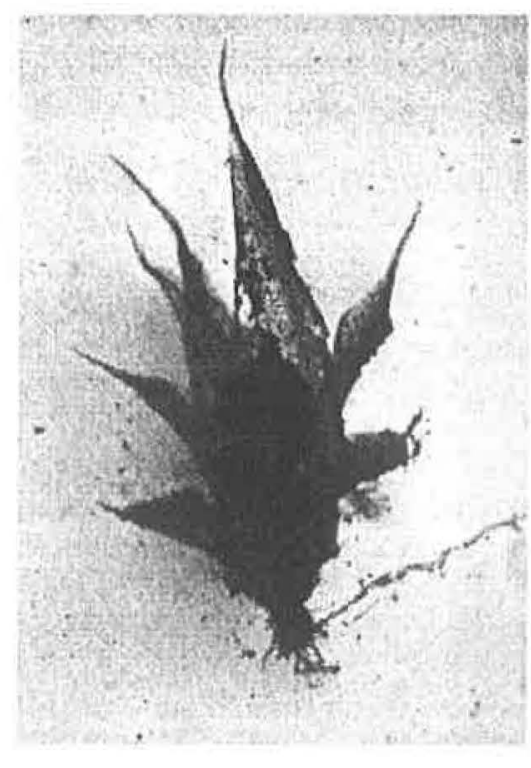

(B)

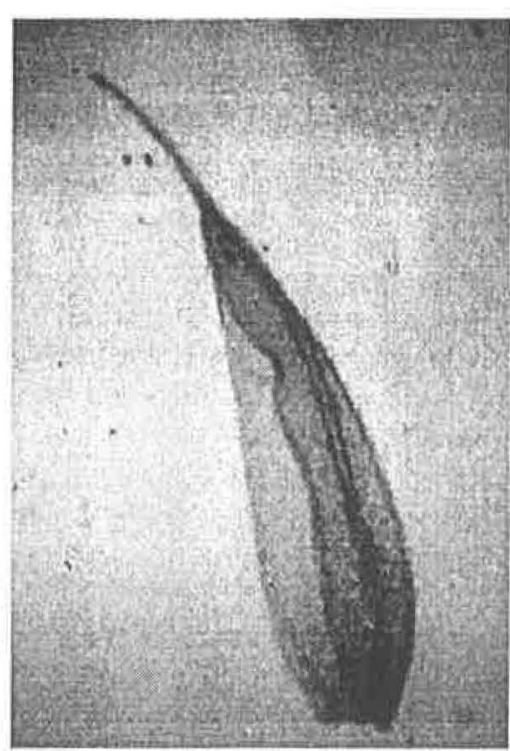

(C)

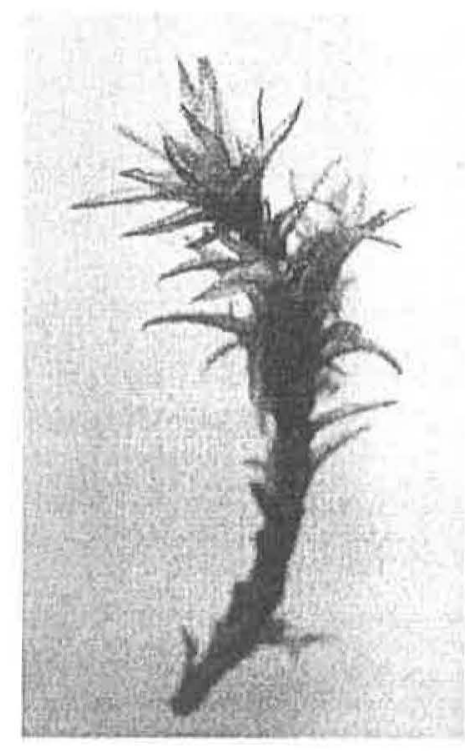

(D)

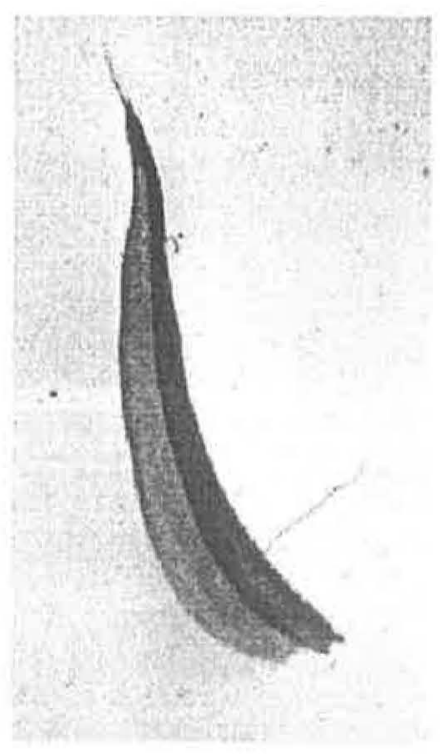

(E)

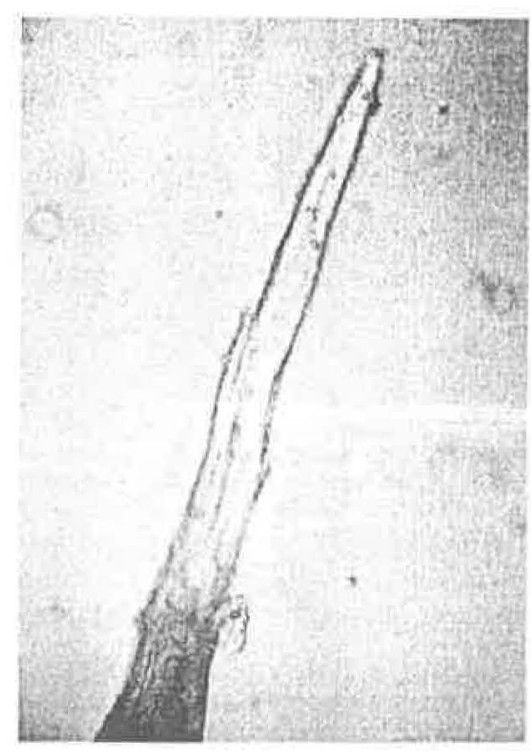

(F)

(Plate,2): A, Phascum curvicolle (x30); B\&C, Phascum cuspidatum var. Piliferum gametophyte plant (x20) \& leaf (x35); D-F, Racomitrium affine gametophyte plant (x37.5), leaf (x30)\& hyaline leaf apex (x300). 


\section{REFERENCES:}

1- Juratzka J., Milde J., Verh. Zool. Bot. Ges. Wien 20: 589-602 (1870).

2- Schiffner, V., Ost Bot Zeitschr. 47: 125-132 (1897).

3- Schiffner, V., Ann. Naturh Mus. Wien 27; $472-504$ (1913).

4- Handel-Mazzetti, H., Ann. Naturh. Mus. Wien, 28: 48-111 (1914).

5- Froehlich, J., Ann. Naturh Mus. Wien, 63: 31-32 (1955).

6- Vondracek, M., Bull. Iraq. Nat. Hist. Inst. 2: 9-100 (1962).

7- Vondracek, M., Bull. Soc. Amis. Sci.Lettres Poznan Ser. D., 6: 117122 (1965).

8- Agnew, S. and Townsend, C.C. Israel J. Bot. 19: 254-259 (1970).

9- Agnew, S., J. Bryol., 7:339-342 (1973).

10- Agnew S., Vondracek M., Feddes Reptorum 86:341-489. (1975)

11- Long, D.G., Rev. Bryol. Lichen. 45: 103 (1979).

12- Al-Ni'ma B. A. B., J. of Edu. \& Sci. 20: 36-44 (1994).

13- Maulood B. K., Rasheed Y. A.,ZANCO, Special Issue (2) proceeding of the third Scientific Conference University of Salahaddin 3-4 June 1997 in Erbil, Iraq: 67-86 (1997).

14- Frey W. and Kurschner H., Bibliotheca Band 39: 181 (1991).

15- Bilewsky F., Nova Hedwigia 9: 335-434 (1965).

16- Macvicar S. M., "The student's handbook of British Hepatic". 2 nd Ed. London: V. V. Sumfield Station Street (1926).

17- Smith A. J. E., "The moss Flora of Britain and Ireland". Cambridge: Cambridge University press (1978).

18- Watson V. E., Richards P. M. A. "British Mosses and Liverworts. Cambridge: Cambridge University Press (1968).

19-Guest E.. "Flora of Iraq". Volume (1), Baghdad: Ministry of Agriculture, Republic of Iraq (1966). 